\title{
LEGUMES IN HIGH-COUNTRY DEVELOPMENT
}

\author{
A. H Nordmeyer and M. R. DAVIS \\ Forest Research Institute, Christchurch
}

\section{Abstract}

On eroded, acid subsoils above $1000 \mathrm{~m}$ Lotus spp. were better adapted than clovers to low phosphorus and high exchangeable aluminium levels in the soil. Lotus grew better and fixed more nitrogen than white clover, and its uptake of aluminum was less than clover. With adequate supplies of fertilizer, lotus and clover fixed up to $140 \mathrm{~kg} \mathrm{~N} / \mathrm{ha} / \mathrm{yr}$, most of which was incorporated in a surface turf. The proportion of lotus in the sward was reduced by the greater production of grass associated with increasing rates of superphosphate.

\section{INTRODUCTJON}

THERE are approximately 1 million hectares of eroded mountainland in New Zealand where an improvement in soil fertility is necessary as a first stage of management. Above $1000 \mathrm{~m}$, the subsoils that are exposed by erosion are usually acid, high in exchangeable aluminium and low in all the major plant nutrients. Temperatures in these soils at $10 \mathrm{~cm}$ depth lie between 5 and 20" C during the growing season.

In the Craigieburn Range, Canterbury. a number of legumes have been compared on subsoils in sown plot trials. Trifolium repens, 'Grasslands Huia' white clover, lotus (Lotus pedunculafusj, and lupin (Lupinus polyphyllus) have persisted. Cultivars of Trifolium pratense (24), T. hyhridum (10), T. repens (19), Lofus pedunculatus (5), and L. corniculatus (20) have been tested as spaced plants at $1200 \mathrm{~m}$. Some cultivars of lotus have persisted, but no clovers survive after 5 years.

Some comparisons of lotus and white clover growing on subsoils in the Craigieburn Range and Kaweka Range (Hawke's Bay) are described.

\section{WHITE CLOVER-LOTUS PEDUNCULATUS COMPARISONS IN - POT $^{-}$TRIALS}

In glasshouse pot trials, legumes growing on a Bealey subsoil from the Craigieburn Range take up different amounts of aluminimum depending on the species and level of added phosphate. White clover contains high concentrations of $\mathrm{Al}$ in the foliage (Fig. 1) and, of the total Al taken up, transports a greater pro- 


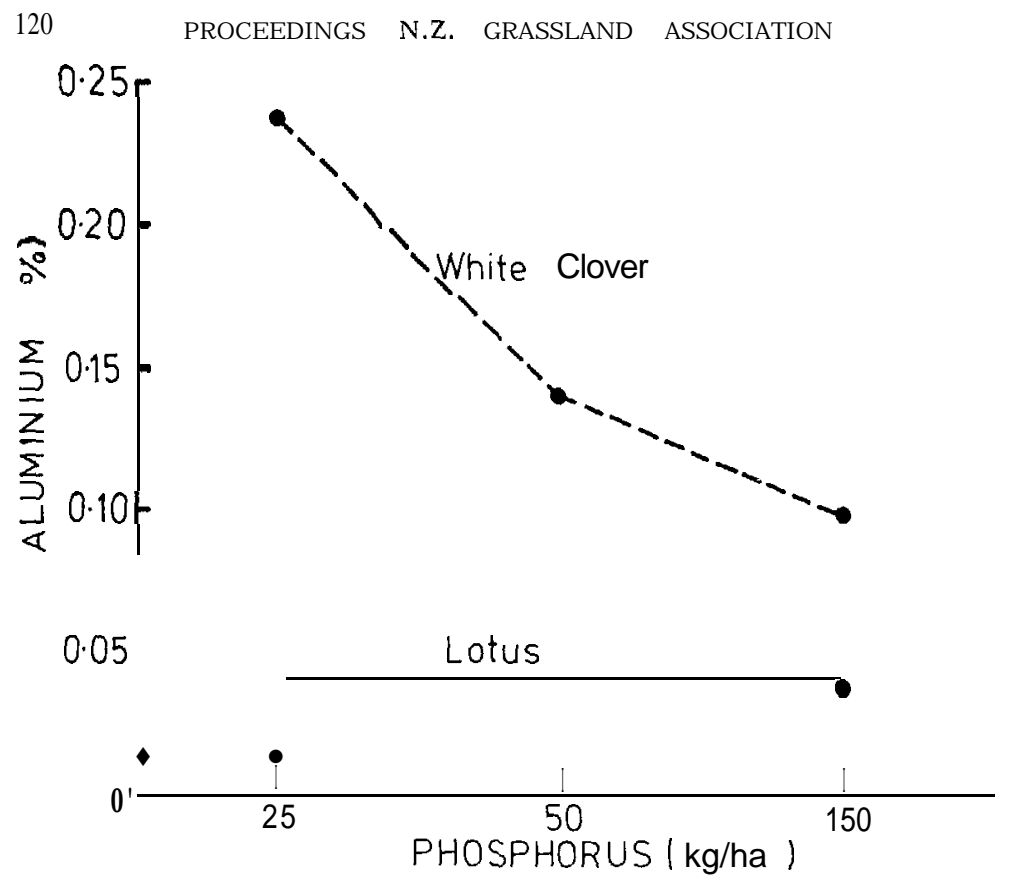

FIG. 1: Aluminium concentrations in shoots of white clover and lotus growing on Bealey subsoil.

portion into the shoots than lotus. Levels of $\mathrm{Al}$ in clover foliage of plants grown on subsoils are extremely high based on comparative work with nutrient solutions (Andrew et al., 1973). It has also been found that white clover needs approximately twice as much phosphate as lotus for maximum growth on this subsoil. These pot trial results help to explain some of the longer-term field trials.

\section{WHITE CLOVER-LOTUS PEDUNCULATUS COMPARISONS IN THE FIELD}

Huia white clover (inoculated with Rhizobium TA1) and commercial diploid, uncertified $\mathrm{L}$. pedunculatus (inoculated with Rhizobium $\mathrm{CC} 814 \mathrm{~s}$ ) have been examined on three areas. over a range of superphosphate levels, with Holcus lanatus (Yorkshire fog) as a companion grass. The results for one of these trials, in the Kaweka Range, are discussed here.

In the first year, white clover grew better than lotus, but lotus improved in the second year and in the third season its DM yield was between 3 and 10 times greater than that of white clover. By the fourth season a turf of roots and litter had 
accumulated on the soil surface. Most of the $\mathrm{N}$ fixed by the legumes remained in the turf and herbage. The total $\mathrm{N}$ figures shown in Fig. 2 do not represent gross fixation as no account is taken of the $\mathrm{N}$ removed in herbage from previous years or of soil $\mathrm{N}$. N:P ratios of herbage, turf and surface soil were consistently higher in lotus than in clover plots, suggesting a more efficient use of $\mathrm{P}$ in $\mathrm{N}$ fixation by lotus. This conclusion was also made from pot trials.

In spite of greater total $\mathrm{N}$ in lotus plots, more grass grew in white clover plots for a given amount of legume herbage. By the fifth season (Fig. 3), lotus still made up most of the total herbage production and was proportionately greater at low levels of superphosphate, whereas clover made up generally less than $30 \%$. of the total production and was proportionately greater at the highest levels of superphosphate.

Gross $\mathrm{N}$ fixation at the Kaweka site by the end of the fourth season was about $350 \mathrm{~kg} \mathrm{~N} / \mathrm{ha}$ on the high superphosphate plots. In the Craigieburn Range, total $\mathrm{N}$ has been approximately doubled by legumes in 5 years, from $640 \mathrm{~kg} \mathrm{~N} / \mathrm{ha}$ on bare subsoil (to $15 \mathrm{~cm}$ depth) to $1340 \mathrm{~kg} \mathrm{~N} / \mathrm{ha}$ (in herbage, turf, roots and soil) of which $47 \%$ is in the superficial turf and $42 \%$ is in the surface ( 0 to $2.5 \mathrm{~cm}$ depth) soil. It appears that annual rates of $\mathrm{N}$ accumilation of 100 to $140 \mathrm{~kg} / \mathrm{ha}$ are possible in the early stages of sward development on exposed subsoils, and that most of this nitrogen is incorporated in a surface mat. Jt is not known how long this rate of fixation can be maintained.

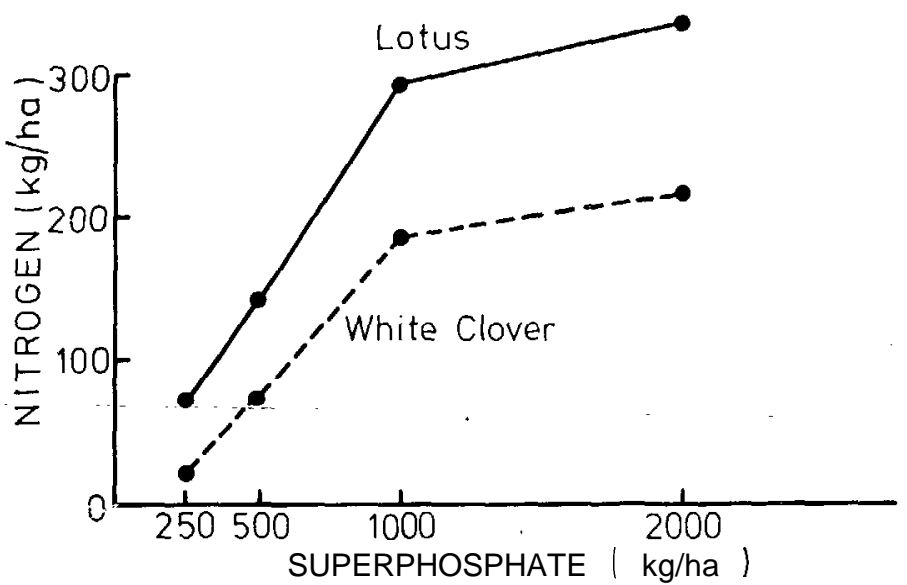

FIG. 2: N itrogen in herbage and turf after $\mathbf{4}$ seasons, Kaw eka Range. 


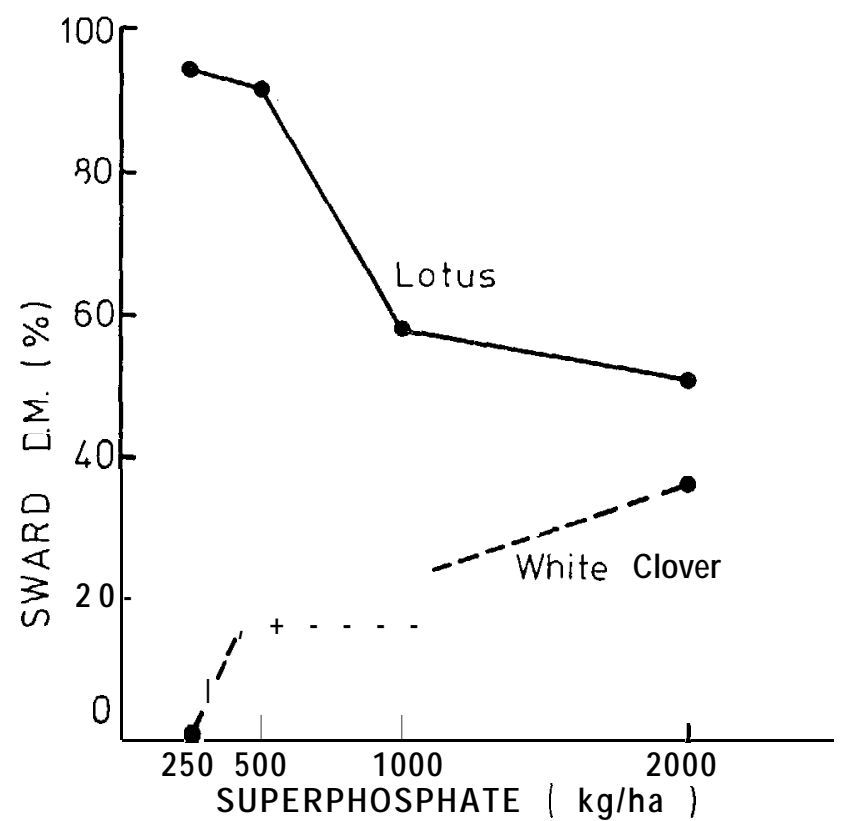

FIG. 3: Proportion of lotus or white clover in total sward DM after 5 seasons. Kaweka Range.

\section{NEW CULTIVARS OF LOTUS}

In recent years Grasslands Division, DSIR, has developed selections of lotus, one of which, 'Grasslands Maku' tetraploid L. pedunculatus Cav. (Armstrong, 1974), has proved to be more easily established and more vigorous than commercial lotus on bare subsoils above $1000 \mathrm{~m}$ in Canterbury, Marlborough, and Hawke's Bay. However, its performance under dry conditions is suspect. A hybrid between tetraploid $L$. pedunculatus and L. corniculafus ('Grasslands 4712') has the deep-rooting habit of $L$. corniculatus and is possibly better adapted to dry sites than Maku.

Maku and G4712 inoculated with Rhizobium CC814s were compared on a dry subsoil site at $1000 \mathrm{~m}$ in the Craigieburn Range with four levels of superphosphate, and with Yorkshire fog as a companion grass. In the first season, Maku grew better than G4712. By the third season (Table 1), the hybrid yielded more than Maku overall, and, unlike Maku, showed an increasing response to the highest level of serpentine superphosphate. Nitrogen concentrations and N: P ratios were higher in Maku 
than in G4712. Presumably the $\mathrm{N}$ content of the two cultivars affected grass yields since there was significantly more grass with Maku than with the hybrid. Whether the Rhizobium strain used (CC814s) was the most effective on both cultivars in the trial area is not known.

TABLE 1: YIELDS OF LOTUS AND GRASS IN THE THIRD SEASON, CRAIGIEBURN RANGE

\begin{tabular}{|c|c|c|c|c|}
\hline \multirow{4}{*}{$\begin{array}{c}\text { Serpentine } \\
\text { superpkospate } \\
(\mathrm{kg} / \mathrm{ha})\end{array}$} & \multicolumn{4}{|c|}{$\begin{array}{c}\text { Dry } M \text { atter } \\
(\mathrm{kg} / \mathrm{ha})\end{array}$} \\
\hline & \multicolumn{2}{|c|}{ Lotus } & \multicolumn{2}{|c|}{ Grass } \\
\hline & Grasslands & G4712 & with & with \\
\hline & M aku & Hybrid & M aku & G4712 \\
\hline 400 & 150 & 280 & 70 & 45 \\
\hline 300 & 435 & 650 & 130 & 40 \\
\hline 1600 & 2000 & 1560 & 160 & 45 \\
\hline 2400 & 1750 & 2265 & 360 & 40 \\
\hline \multicolumn{5}{|l|}{ Significance: } \\
\hline \multirow{3}{*}{$\begin{array}{l}\text { Superphosphate } \\
\text { Lotus cultivar } \\
\text { Superphosphate } \\
\text { cultivar }\end{array}$} & \multicolumn{2}{|c|}{$P<0.01$} & \multicolumn{2}{|c|}{$P<0.01$} \\
\hline & \multicolumn{2}{|c|}{$P<0.1$} & \multicolumn{2}{|c|}{$P<0.01$} \\
\hline & \multicolumn{2}{|c|}{$p<0.01$} & \multicolumn{2}{|c|}{$P<0.01$} \\
\hline
\end{tabular}

\section{DISCUSSION}

It appears that Al toxicity is a major factor affecting plant growth and species differentiation on acid subsoils. The reasons why $L$. pedunculatus grows well on these soils are apparently related to its ability to withstand high levels of available aluminium combined with an ability to make relatively efficient use of fertilizer $\mathrm{P}$ for $\mathrm{N}$ fixation and growth. Total uptake of $\mathrm{Al}$ is lower in lotus than in white clover and the amount transported to the shoot is about half that of white clover. Tolerance to Al toxicity may not entirely explain the superior performance of lotus on subsoils, since on soils where available Al was probably low Maku lotus grew as well as or better than white clover (Brock, 1973; Gibson et al., 1975).

In spite of the greater quantity of nitrogen and the wider $\mathrm{N}: \mathrm{P}$ ratios of herbage, turf and soil of lotus plots, the DM yield of grass associated with lotus is lower than that growing with white clover. Presumably, the short-' and long-term mineralization of organic $\mathrm{N}$ under lotus is less than with clover. Even amongst lotus lines (Maku vs G4712) there are differences in the amounts of associated grass which are related to the $\mathrm{N}$ concentration of the legume component. 
It is apparent that on acid subsoils growth and $\mathrm{N}$ fixation are strongly dependent on the level of superphosphate applied. From the shape of the curves of species composition (Fig. 3) it might be speculated that high levels of maintenance superphosphate could depress the content and ultimately the $\mathrm{N}$-fixing function of lotus through grass competition, whereas high levels of superphosphate would be necessary to maintain or increase the $\mathrm{N}$ fixed by clover as grass competition increases with improved supplies of mineralized $\mathrm{N}$. Very little is known about Lotus pedunculatus in swards, but it would appear that its response to superphosphate and to grass competition is different from white clover's (Jackman and Mouat, 1972). On present evidence lotus looks promising for the early stages of revegetation up to treeline, but it may not be the best legume for dry sites, or under conditions of intense grass competition.

\section{IMPLICATIONS FOR TUSSOCK GRASSLAND DEVELOPMENT}

The introduction of legumes combined with fertilizers will initiate a cycle of organic matter and nitrogen accumulation on eroded soils that will tend towards some new equilibrium level depending on site, climate and management. If the period required for half the change in organic matter is related to the mineralization rate $(k 1)$ by the formula $T 1 / 2=0.693 / k 1$ (Russell, 1962), and assuming that $k 1$ is very low $(0.2$ to $0.5 \%)$ because of low $\mathrm{pH}$, low soil temperatures, and the presence of allophane, then 100 to 300 years may be needed for half the change to occur. These estimates suggest that. compared with pasture land in warmer environments (Jackman, 1964), tussock grassland soils will take a much longer time to reach a new organic matter equilibrium level, and a continuing source of $\mathrm{N}$, $\mathrm{P}$ and $\mathrm{S}$ will be necessary for this new equilibrium to be reached and for sustained soil fertility. Under these conditions, one legume species or cultivar may not be adapted to all phases of changing fertility and competition, and there could be a need for a succession of legumes for the most efficient $\mathrm{N}$ fixation over a period of time. Eventually there may be a requirement for a strongly perennial legume with a large amount of capital tissue to provide some measure of competition for light with the taller native grasses and shrubs.

On these grounds, the simple extension of the white cloverryegrass heavy grazing regime that suits some situations in the lowlands is not likely to be the best management system in the colder tussock grasslands. It will be necessary to maintain a 
large amount of standing vegetation in order to get the combined benefits of watershed protection, organic matter accumulation, and some form of production.

\section{REFERENCES}

Andrews, C. S.; Johnson, A. D.; Sandland, R. L., 1973. Aust. J. agric. Res., 24: 325-39.

Armstrong, C. S., 1974. N.Z. Il exp. Agric., 2: 333-6.

Brock, J. L., 1973. N.Z. $I l$ agric. Res., 16: 483-91.

Gibson, D. I.; Hayes, P.; Laidlaw, A. S., 1975. J. Rr. Grassld Soc., 30: 295-301.

Jackman, R. H., 1964. N.Z. Jl agric. Res., 7: 445-71.

Jackman, R. H.: Mouat. M. C. H., 1972. Ibid., 15: 653-66.

Russell, J. S., 1962. Trans. int. Soc. Soil Sci., it M eet. Comm. IV, V, pp. 191-6. 